\title{
Influence of Some Pregerminaton Treatments on Seed Germination and Seedling Quality of Two Ornamental Palm Species Common in Egypt \\ II- Pygmy Date Palm (Phoenix roebelenii O`Brien)
}

\author{
Sayed M. Shahin and Hesham F. El-Tayeb \\ Botanical Gardens Res. Dept., Hort. Res. Inst., ARC, Giza, Egypt
}

\begin{abstract}
This investigation was undertaken under the shade at the Nursery of Antoniades Botanical Garden, Hort. Res. Inst., Alexandria, Egypt during 2014 and 2015 seasons to study the effect of the following pregermination treatments: untreated intact fruits (as control), depulped seeds (Pyrenes) without any treatment, soaking the depulped seeds in tap water for either 24 or 48 hours, soaking the depulped seeds in hot water $\left(60-70^{\circ} \mathrm{C}\right)$ for 24 hours or soaking them in diluted sulphuric acid $(50 \%)$ for either 6 or 12 hours on germination characters of Pygmy date palm (Phoenix roebelenii O'Brien) seeds and growth and quality of the resulted seedlings. The obtained results indicated that soaking the depulped seeds in tap water for $24 \mathrm{~h}$. treatment gave the highest percentage of germination in the two seasons and followed in the first season by soaking in hot water for $24 \mathrm{~h}$ treatment, but in the second one by the untreated depulped seeds. The depulped seeds soaked in diluted $\mathrm{H}_{2} \mathrm{SO}_{4}(50 \%)$ for $6 \mathrm{~h}$. failed to germinate in both seasons, while those soaked in such acid for $12 \mathrm{~h}$. gave $10 \%$ germination only in the first season. The least number of days passed to either the highest percent of germination (G.V.) or $50 \%$ germination (MGR) in the two seasons was also recorded by soaking in tap water for $24 \mathrm{~h}$. treatment. The germination rate index (GRI) was significantly increased over control by depulping and soaking in tap water for $48 \mathrm{~h}$. treatments, but slightly decreased by soaking in tap water for $24 \mathrm{~h}$. and significantly by soaking in hot water for $24 \mathrm{~h}$. treatments compared to control in the two seasons. Most of the used treatments improved the means of vigour index (V.I.), seed viability (S.V.), plumule length, vegetative and root growth parameters of the produced seedling, as well as their leaf content of pigments and total soluble sugars with various significant differences relative to control means in most cases of both seasons. However, the mastership was recorded for treatment of soaking in tap water for $24 \mathrm{~h}$., which gave the utmost highest values in most of the previous measurements in the two seasons. So, it can be recommended to soak the depulped seeds (Pyrenes) of Pygmy date palm (Phoenix roebelenii O'Brien) in tap water for 24 h. to achive the highest and fastest germination along with the best quality of the seedlings.
\end{abstract}

Keywords: Phoenix roebelenii O’Brien, germination, soaking, thermal scarification, mechanical scarification, chemical scarification.

\section{INTRODUCTION}

Pygmy date palm (Phoenix roebelenii O`Brien) belongs to Fam. Arecaceae is a small to medium sized, slow-growing slender tree growing to 2-3 $\mathrm{m}$ tall. The leaves are 60-120 cm long, pinnate, with around 100 leaflets arranged in a single plane. Each leaflet is $15-25 \mathrm{~cm}$ long and $1 \mathrm{~cm}$ broad, slightly drooping and grey-green in colour. The fruit is an edible $1 \mathrm{~cm}$ drupe resembling a small, thin fleshed date, violet-black in colour when mature and the seed shows a longitudinal furrow. They are very much appreciated by birds and one kilogram contains 3663 seeds (Lorenzi et al. 2004).

Pygmy date palm is a popular ornamental plant in gardens in tropical and subtropical areas. In cooler area, it is grown under glass or as a house plant. It is resistant to pests, tolerant to soil variation and moderately drought tolerant. It grows in partial shade to full sun and needs little pruning to develop a strong structure. It excels in containers of all kinds, also looks great by patios and entry ways. Use clumps of this palm as specimens and to serve as focal point in a mass planting of annuals. Also, nice combined with evergreen shrubs in a 
mixed hedges. This palm is said to remove formaldehyde and xylene from air (Barrow, 1994).

The seeds of $P$. roebelenii (Pyrenes) are elliptical or cylindrical and slightly flattened. They are albuminous, with a very hard endosperm almost completely filling its inner part. So, they must be soaked in water for at least 24 hours (Lossi et al. 2006). P. roebelenii seed germination is of the remotetubular type, in which the cotyledon petiole is considerably elongated and no ligula is visible (Uhl and Dransfield, 1997). Matthes and Castro (2007) reported that seeds from three different locations and harvest times started to germinate $47,60,120$ days after sowing. This difference may be ascribed to the genetic factor, the climatic conditions under which the plant develops or stage of fruit maturation.

Little studies were carried out on seed germination of species belongs Phoenix genus, especially under environment of Egypt such as that of Shahin et al. (2014) who found that soaking the depulped seeds of Phoenix rupicola in either concentrated $\mathrm{H}_{2} \mathrm{SO}_{4}$ for 4 min or tap water for $3 \mathrm{~h}$. increased germination percentage to 100 and $80 \%$, respectively. These two treatments have also improved germination velocity, mean germination rate, germination rate index, vigour index, seed viability, plumule length, vegetative and root growth of the resulted seedlings and their leaf content of pigments, total carbohydrates and total indoles. On the other side, great efforts were done in relation to the germination of seeds of other palms, such as those revealed by Shahin and Arafa (2014 a and b) on Butia capitata and Hyphaene thebaica, Al-Fredan and Ali (2008) on Doum, Junior et al. (2013) on Acrocomia aculeata and Shahin et al. (2014) on Syagrus schizophylla.

However, this investigation aims to find out the best pregermination treatment reliable for germination enhancing and accelerating of Pygmy date palm seeds with high quality of the resulted seedlings.

\section{MATERIALS AND METHODS}

This study was carried out under the shade at the nursery of Antoniades Botanical Garden, Hort. Res. Inst., Alexandria, Egypt throughout the two consecutive seasons of 2014 and 2015 to examine the effect of some presowing treatments on germination traits and quality of the seedlings that will be formed from Pygmy date palm treated seeds.

Therefore, the mature fruits of Pygmy date palm (Phoenix roebelenii O`Brien) were collected from trees located on Antoniades Botanical Garden, Alexandria, from mid to end of March for each season. The pulp of the fruit was removed. Next, the pyrenes (which consisted of the endocarp and seed) were washed in running water and dried in the shade for one day. On April, $1^{\text {st }}$ for each season, the depulped seeds (pyrenes, the mean weight of 10 pyrenes was about $1.42 \mathrm{~g}$ ) received the following treatments:

1. Untreated depulped seeds.

2. Depulped seeds soaked in tap water for either 24 or 48 hours under ambient conditions.

3. Depulped seeds soaked in hot water $\left(60-70{ }^{\circ} \mathrm{C}\right)$ for 48 hours as thermal scarification treatment. 
4. Depulped seeds soaked in diluted sulphuric acid (50\%) for either 6 or 12 hours under ambient conditions.

Besides, the intact fruits (undepulped seeds) which raised without any treatment as control (the mean weight of 10 intact fruits was about $1.83 \mathrm{~g}$ ). Before, sowing the treated pyrenes and intact fruits of control treatment were surface sterilized with $10 \%$ Na-hydrochloride for 10 min., they rinsed several times with sterile distilled water and sown in 16-cm-diameter plastic pots (10 seeds or fruits/pot) filled with about $1.5 \mathrm{~kg}$ of sand and clay mixture (at equal ratios by volume). The physical and chemical analyses of the sand and clay used in both seasons are shown in Table (1).

Table (1). The physical and chemical analyses of the used sand and clay in both seasons.

\begin{tabular}{|c|c|c|c|c|c|c|c|c|c|c|c|c|}
\hline \multirow{2}{*}{$\begin{array}{l}\text { Soil } \\
\text { type }\end{array}$} & \multicolumn{3}{|c|}{$\begin{array}{c}\text { Particle size } \\
\text { distribution (\%) }\end{array}$} & \multirow{2}{*}{\multicolumn{3}{|c|}{ S.P. $\begin{array}{c}\text { E.C. } \\
(\mathrm{dS} / \mathrm{m})\end{array}$}} & \multicolumn{3}{|c|}{ Cations (meq/L) } & \multicolumn{3}{|c|}{ Anions (Meq/L) } \\
\hline & $\begin{array}{l}\text { Coarse Fine } \\
\text { sand sand }\end{array}$ & Silt & Clay & & & & $\mathrm{Ca}^{++} \mathrm{Mg}^{+}$ & & & & & \\
\hline & & & & & & & & & & & & \\
\hline & 8621 . & & & & .21 & & & & & & & \\
\hline
\end{tabular}

The pots were arranged in a completely randomized design (Silva and Azevedo, 2009), replicated thrice as each pot containing 10 seeds exemplifies a replicate. Clearly visible plumule protrusion was used as criterion for germination. All agricultural practices needed for such plantation was carried out on time. Data were recorded as follows:

A. Germination characteristics:-

1- Germination percentage ( $G \%$ ) from the following equation:

G. $\%=$ (No. germinated seeds/ Total No. sown seeds) $\times 100$

2- Germination velocity (G.V.) in days, which equal average number of days from sowing till emergence of the final plumule.

3- Mean germination rate (MGR) in days = mean number of days till $50 \%$ germination (Odetola, 1987).

4- Germination rate index (GRI), which calculated from Bartled equation indicated by Hartmann and Kester (1983). $G R I=A+(A+B)+(A+B+$ C) $+\ldots / \mathrm{N}(\mathrm{A}+\mathrm{B}+\mathrm{C} \ldots .$.$) .$

- Where: $A, B, C, \ldots$ etc. are number of germinated seeds counted at different times, and $\mathrm{N}$ is number of times at which the germinated seeds were counted.

5- Vigour index $(\mathrm{VI})=\mathrm{G} \% \mathrm{x}$ mean length of plumule (Selvaraju and Selvaraj, 1994)

6- Seed viability $(\mathrm{SV})=$ number of survived seedlings in each treatment after excluding the deteriorated and dead ones (Odetola, 1987).

7- Plumule length of the germinated seeds $(\mathrm{cm})$. 


\section{B. Seedling growth characters:-}

At the end of each season (on August, $20^{\text {th }}$ ), seedlings from the different treatments were gently lifted to measure the following data: the lengths of seedling, sheath, leaf and petiole $(\mathrm{cm})$, number of leaves / seedling, root length $(\mathrm{cm})$, number of root branches per main root and leaves and roots fresh and dry weights (g).

\section{Chemical determinations:-}

In fresh leaf samples, photosynthetic pigments (chlorophyll a, b and carotenoids, mg/g. f.w.) and total soluble sugars (mg/100 g f.w.) were determined using the methods described by Yadava (1986) and Dubois et al. (1966), respectively.

The collected data were then tabulated and statistically analysed using SAS Institute (2009) program, which was followed by Duncan's New Multiple Range Test (Steel and Torrie, 1980) for elucidating the significancy between the means of various treatments at $5 \%$ level.

\section{RESULTS AND DISCUSSION}

\section{Effect of pre-germination treatments on: 1- Germination characteristics:}

According to data averaged in Table (2), it was noticed that soaking the depulped seeds in tap water for $24 \mathrm{~h}$ treatment significantly increased the percent of germination to the highest values compared to other treatments in the two seasons, and followed in the first season by soaking in hot water for 24 h. treatment $(67.33 \%)$, but in the second one by untreated deepulped seeds $(70.33 \%)$. The least improvement in this parameter was gained in the $1^{\text {st }}$ season by untreated depulped seeds and those soaked in tap water for $48 \mathrm{~h}$., as these two treatments raised germination $\%$ to $60 \%$ against $50 \%$ for the control, while in the $2^{\text {nd }}$ one, that was attained by soaking the depulped seeds in either tap water for $48 \mathrm{~h}$. or hot water for $24 \mathrm{~h}$. treatments, which elevated the mean of such trait also to $60 \%$ versus $47.5 \%$ for control. On the other hand, the depulped seeds soaked in diluted $\mathrm{H}_{2} \mathrm{SO}_{4}$ for any time failed to germinate in the two seasons except of soaking for $12 \mathrm{~h}$ treatment that scored $10 \%$ germination in the $1^{\text {st }}$ season only. This may be due to exposure the embryo to injury by the acid. In this regard, Chikumba et al. (2006) mentioned that the 10min acid treatment increased germination of Macrotyloma deltonii seeds from 21 to $38 \%$, but 20-min treatment reduced germination and increased the number of dead seeds.

The least number of days lapsed to reach either the highest germination $\%$ (G.V.) or $50 \%$ germination (MGR) was also recorded by soaking treatment in tap water for $24 \mathrm{~h}$ with significant differences when compared to control and other treatments in the two seasons. The germination rate index (GRI), as a real indicator for germination accelerating was significantly increased over control by depulped seeds and soaking in tap water for $48 \mathrm{~h}$ in both seasons, as well as by soaking in diluted acid in the first season, but slightly decreased by soaking in tap water for $24 \mathrm{~h}$ treatment and significantly by soaking in hot water for $24 \mathrm{~h}$. 
relative to control in both seasons. As for vigour index (V.S.), seed viability (S.V.) and plumule length $(\mathrm{cm})$ parameters, they were significantly improved by the most treatments used in such trial, with the superiority of soaking in tap water for $24 \mathrm{~h}$. treatment which gave the highest records in this traits in the two seasons.This may be attributed to ability of tap water to penetrate the hard endosperm of Pygmy date palm seeds in amount sufficient to activate enzymes which decay the complex nutritional substances stored in this hard endosperm to produce the energy necessary for embryo growth. In this concern, Al-Fredan and Ali (2008) mentioned that soaking doum seeds in water for $24 \mathrm{~h}$. is needed after mechanical scarification treatment to activate growth of the embryo. Junior et al. (2013) noticed that immersing macaw palm seeds in tap water after removing the orpecular tegument progressively increased the germination speed index with elongating the immersing time. The previous results were supported by those declared by Lossi et al. (2006) on Phoenix roebelenii, Shahin et al. (2014) on Phoenix rupicola and Shahin et al. (2014) on Syagrus schizophylla.

Table (2). Effect of pre-germination treatments on germination traits of Phoenix roebelenii O'Brien palm seeds during 2014 and 2015 seasons.

\begin{tabular}{|c|c|c|c|c|c|c|c|}
\hline $\begin{array}{l}\text { Pre-germination } \\
\text { treatments }\end{array}$ & $\begin{array}{l}\text { Germination } \\
\text { percentage } \\
\text { (G. \%) }\end{array}$ & $\begin{array}{l}\text { Germination } \\
\text { velocity } \\
\text { (G.V., day) }\end{array}$ & $\begin{array}{c}\text { Mean } \\
\text { germination } \\
\text { rate (MGR, } \\
\text { day) } \\
\end{array}$ & $\begin{array}{l}\text { Germination } \\
\text { rate index } \\
\text { (GRI) }\end{array}$ & $\begin{array}{l}\text { Vigour index } \\
\text { (VI) }\end{array}$ & $\begin{array}{l}\text { Seed viability } \\
\text { (S.V.) }\end{array}$ & $\begin{array}{l}\text { Plumule } \\
\text { length }(\mathrm{cm})\end{array}$ \\
\hline \multicolumn{8}{|c|}{ First season: 2014} \\
\hline Control & $50.00 d$ & $117.67 a$ & $117.67 a$ & $0.67 \mathrm{c}$ & $70.00 \mathrm{c}$ & $5.00 \mathrm{c}$ & $1.40 \mathrm{~cd}$ \\
\hline Depulped seeds (DS) & $60.00 \mathrm{c}$ & $101.00 c$ & $93.58 \mathrm{c}$ & $0.78 b$ & $108.60 b$ & $6.10 b c$ & $1.81 b$ \\
\hline $\begin{array}{l}\text { DS soaked in tap } \\
\text { water for } 24 \mathrm{~h} \text {. }\end{array}$ & $80.76 a$ & $89.72 d$ & $80.50 d$ & $0.61 \mathrm{c}$ & $170.40 \mathrm{a}$ & $8.76 a$ & $2.11 \mathrm{a}$ \\
\hline $\begin{array}{l}\text { DS soaked in tap } \\
\text { water for } 48 \mathrm{~h} \text {. }\end{array}$ & $60.00 \mathrm{c}$ & $108.25 b$ & $103.69 \mathrm{bc}$ & $0.71 b$ & $97.80 \mathrm{bc}$ & $6.00 \mathrm{bc}$ & $1.63 b$ \\
\hline & $67.33 b$ & $110.78 b$ & $107.33 b$ & $0.53 d$ & $101.00 \mathrm{~b}$ & $6.73 b$ & $1.50 \mathrm{c}$ \\
\hline $\begin{array}{l}\text { DS Soaked in diluted } \\
\mathrm{H}_{2} \mathrm{SO}_{4} \text { for } 6 \mathrm{~h} \text {. }\end{array}$ & $0.00 f$ & - & - & - & - & - & - \\
\hline $\begin{array}{l}\text { DS Soaked in diluted } \\
\mathrm{H}_{2} \mathrm{SO}_{4} \text { for } 12 \mathrm{~h} \text {. }\end{array}$ & $10.00 \mathrm{e}$ & $99.00 c$ & - & $1.00 \mathrm{a}$ & $12.3 d$ & $0.00 d$ & $1.23 d$ \\
\hline \multicolumn{8}{|c|}{ Second season: 2015} \\
\hline Control & $47.50 d$ & $125.91 \mathrm{a}$ & - & $0.71 b$ & $69.35 d$ & $4.33 d$ & $1.46 \mathrm{c}$ \\
\hline Depulped seeds (DS) & $70.33 b$ & $107.63 c$ & $99.00 \mathrm{~b}$ & $0.82 a$ & $133.63 b$ & $7.00 \mathrm{~b}$ & $1.90 \mathrm{ab}$ \\
\hline $\begin{array}{l}\text { DS soaked in tap } \\
\text { water for } 24 \mathrm{~h} \text {. }\end{array}$ & $90.00 a$ & $90.96 d$ & $83.46 c$ & $0.63 b c$ & $189.00 \mathrm{a}$ & $9.00 a$ & $2.10 \mathrm{a}$ \\
\hline $\begin{array}{l}\text { DS soaked in tap } \\
\text { water for } 48 \mathrm{~h} \text {. }\end{array}$ & $60.00 \mathrm{c}$ & $115.50 \mathrm{~b}$ & $109.50 \mathrm{a}$ & $0.76 a b$ & $102.60 \mathrm{c}$ & $6.00 \mathrm{c}$ & $1.71 b$ \\
\hline $\begin{array}{l}\text { DS soaked in hot } \\
\text { water for } 24 \mathrm{~h} \text {. }\end{array}$ & $60.00 \mathrm{c}$ & $117.31 b$ & $110.76 a$ & $0.61 c$ & $97.80 \mathrm{c}$ & $6.00 \mathrm{c}$ & $1.63 b$ \\
\hline $\begin{array}{l}\text { DS Soaked in diluted } \\
\mathrm{H}_{2} \mathrm{SO}_{4} \text { for } 6 \mathrm{~h} \text {. }\end{array}$ & $0.00 \mathrm{e}$ & - & - & - & - & - & - \\
\hline $\begin{array}{l}\text { DS Soaked in diluted } \\
\mathrm{H}_{2} \mathrm{SO}_{4} \text { for } 12 \mathrm{~h} \text {. }\end{array}$ & $0.00 \mathrm{e}$ & - & - & - & - & - & - \\
\hline
\end{tabular}




\section{2- Seedling growth parameters:}

Parallel results to those of germination characteristics were also attained regarding vegetative and root growth parameters of the seedlings generated from the respondent treated seeds (Tables, 3 and 4), where the means of the lengths of seedlings, sheath, leaf, petiole and root $(\mathrm{cm})$, No. leaves/seedling, No. root branches/main root, as well as leaves and roots fresh and dry weights (g) were pronouncedly improved by most employed treatments with the dominance of soaking in tap water one for $24 \mathrm{~h}$., which registered the utmost high means over the control and other treatments in most cases of both seasons. In general, the untreated depulped seeds and those were soaked in either tap eater for $48 \mathrm{~h}$. or hot water for $24 \mathrm{~h}$ gave values closely near together with non-significant differences in between in most instances of the two seasons.

Table (3). Effect of pre-germination treatments on growth traits of Phoenix roebelenii O'Brien palm seedlings during 2014 and 2015 seasons.

\begin{tabular}{|c|c|c|c|c|c|c|c|}
\hline Pre-germination treatments & $\begin{array}{l}\text { Seedling } \\
\text { length } \\
\text { (cm) }\end{array}$ & $\begin{array}{l}\text { Sheath } \\
\text { length } \\
(\mathrm{cm})\end{array}$ & $\begin{array}{l}\text { Leaf } \\
\text { length } \\
\text { (cm) }\end{array}$ & $\begin{array}{c}\text { Petiole } \\
\text { length } \\
(\mathbf{c m})\end{array}$ & $\begin{array}{c}\text { No. leaves } \\
\text { per } \\
\text { seedling }\end{array}$ & $\begin{array}{c}\text { Root } \\
\text { length } \\
\text { (cm.) }\end{array}$ & $\begin{array}{c}\text { No. root } \\
\text { branches } \\
\text { per main } \\
\text { root }\end{array}$ \\
\hline & \multicolumn{7}{|c|}{ First season: 2014} \\
\hline Control & $11.88 d$ & $1.50 \mathrm{~b}$ & $9.80 \mathrm{c}$ & $1.50 \mathrm{c}$ & $1.00 \mathrm{c}$ & $12.00 \mathrm{c}$ & $1.00 \mathrm{c}$ \\
\hline Depulped se & & $1.81 \mathrm{ab}$ & $11.38 b$ & & & $3 a b$ & $\mathrm{Ob}$ \\
\hline water for $\mathbf{2 4 ~ h . ~}$ & & $2.00 \mathrm{a}$ & 14. & & & & $3.00 \mathrm{a}$ \\
\hline ater for $48 \mathrm{~h}$. & $.07 c$ & $1.67 b$ & & 2.2 & & & $1.76 b$ \\
\hline lot water for $24 \mathrm{~h}$. & $14.83 \mathrm{c}$ & 1.80ab & $10.29 c$ & $2.14 b$ & $2.00 \mathrm{~b}$ & $16.00 \mathrm{a}$ & $2.00 \mathrm{~b}$ \\
\hline DS Soaked in diluted $\mathrm{H}_{2} \mathrm{SO}_{4}$ for $6 \mathrm{~h}$. & - & - & - & - & - & - & - \\
\hline \multirow[t]{2}{*}{ DS Soaked in diluted $\mathrm{H}_{2} \mathrm{SO}_{4}$ for $12 \mathrm{~h}$. } & - & - & - & - & - & - & - \\
\hline & \multicolumn{7}{|c|}{ Second season: 2015} \\
\hline Control & $12.47 c$ & $1.59 b$ & $10.00 \mathrm{c}$ & $1.53 c$ & $1.00 \mathrm{c}$ & $10.68 c$ & $1.00 \mathrm{c}$ \\
\hline Depulpe & $15.98 b$ & $1.90 \mathrm{ab}$ & $12.07 \mathrm{~b}$ & $2.31 b$ & $2.00 \mathrm{~b}$ & $13.67 b$ & $1.33 b c$ \\
\hline & $18.79 a$ & $2.10 \mathrm{a}$ & $13.64 a$ & $3.68 a$ & $3.00 \mathrm{a}$ & & $2.16 a$ \\
\hline DS s & $15.01 b$ & $1.76 \mathrm{~b}$ & $10.50 \mathrm{c}$ & $2.30 \mathrm{~b}$ & $1.90 \mathrm{~b}$ & $13.65 b$ & $1.50 \mathrm{~b}$ \\
\hline d in hot water for $24 \mathrm{~h}$. & $15.27 b$ & $1.83 a b$ & $10.47 c$ & $2.33 b$ & $1.78 b$ & $14.25 a b$ & $1.50 \mathrm{~b}$ \\
\hline d in diluted $\mathrm{H}_{2} \mathrm{SO}_{4}$ for $6 \mathrm{~h}$. & - & - & - & - & - & - & - \\
\hline DS Soaked in diluted $\mathrm{H}_{2} \mathrm{SO}_{4}$ for $12 \mathrm{~h}$. & - & - & - & - & - & - & - \\
\hline
\end{tabular}

- Means within a column having the same letters are not significantly different according to Duncan's New Multiple Range Test at $5 \%$ level.

Table (4) Effect of pre-germination treatments on leaves and roots fresh and dry weights of Phoenix roebelenii O'Brien seedlings during 2014 and 2015 seasons.

\begin{tabular}{|c|c|c|c|c|c|c|c|c|}
\hline \multirow{3}{*}{ Pre-germination treatments } & \multicolumn{4}{|c|}{ Leaves } & \multicolumn{4}{|c|}{ Roots } \\
\hline & \multicolumn{2}{|c|}{$\overline{\text { Fresh weight }(\mathrm{g})}$} & \multicolumn{2}{|c|}{ Dry weight (g) } & \multicolumn{4}{|c|}{ Fresh weight (g) Dry weight (g) } \\
\hline & 2014 & 2015 & 2014 & 2015 & 2014 & 2015 & 2014 & 2015 \\
\hline Control & $0.11 \mathrm{c}$ & $0.12 \mathrm{c}$ & $0.03 \mathrm{~b}$ & $0.03 c$ & $0.10 \mathrm{~b}$ & $0.09 c$ & $0.05 b$ & $0.04 b$ \\
\hline Depulped seeds (DS) & $0.20 b$ & $0.19 b$ & $0.07 a b$ & $0.08 b$ & $0.019 a$ & $0.17 a b$ & $0.09 a$ & $0.08 a b$ \\
\hline DS soaked in tap water for $24 \mathrm{~h}$. & $0.32 a$ & $0.30 \mathrm{a}$ & $0.10 \mathrm{a}$ & $0.13 a$ & $0.018 \mathrm{a}$ & $0.19 a$ & $0.10 \mathrm{a}$ & $0.12 \mathrm{a}$ \\
\hline DS soaked in tap water for $48 \mathrm{~h}$. & $0.17 \mathrm{~b}$ & $0.19 \mathrm{~b}$ & $0.05 b$ & $0.07 b$ & $0.12 b$ & $0.14 b$ & $0.06 a b$ & $0.07 b$ \\
\hline DS soaked in hot water for $24 \mathrm{~h}$. & $0.19 b$ & $0.20 \mathrm{~b}$ & $0.06 \mathrm{ab}$ & $0.07 b$ & $0.21 \mathrm{a}$ & $0.19 a$ & $0.10 \mathrm{~b}$ & $0.09 a b$ \\
\hline DS Soaked in diluted $\mathrm{H}_{2} \mathrm{SO}_{4}$ for $6 \mathrm{~h}$. & - & - & - & - & - & - & - & - \\
\hline DS Soaked in diluted $\mathrm{H}_{2} \mathrm{SO}_{4}$ for $12 \mathrm{~h}$ & - & - & - & - & - & - & - & - \\
\hline
\end{tabular}


The previous findings could be interpretted and discussed as indicated before in case of germination characters. However, they are in harmony with those detected by Shahin et al. (2014) on Phoenix rupicola and Alamgir and Hossain (2005) whom found that immersing Albizia saman in tap water for 25 $\mathrm{h}$. increased germination percentage, germination velocity, vigour index, initial morophological growth and biomass production of the seedlings. Likewise, Dhanda et al. (2011) pointed out that tap water treatment improved seed germination of Albizia lebbek, Acacia catechu and Melia azadirach and pronouncedly increased seedling growth, number of nodules and biomass production.

\section{3- Leaf content of pigments and sugars:}

Data illustrated in Table (5) clear that leaf content of chlorophyll a, b and carotenoids (mg/g f.w.), as well as total soluble sugars (mg/100 g f.w.) were markedly increased over control in the two seasons by depulping treatment and soaking in either tap water or hot water ones with the mastery of soaking in tap water for $24 \mathrm{~h}$. treatment that recorded, generally the highest content of the aforenamed constituents compared to control and the other treatments in both seasons, except of carotenoids content in the first season, as the depulping treatment raised such component to the utmost high mean. In general, depuling treatment occupied the second position as it gave the second highest content in all previous constituents immediately after the tap water treatment for $24 \mathrm{~h}$.

Table (5). Effect of pre-germination treatments on some active constituents in the leaves of Phoenix roebelenii O'Brien seedlings during 2014 and 2015 seasons.

\begin{tabular}{|c|c|c|c|c|c|c|c|c|}
\hline \multirow{3}{*}{ Pre-germination treatments } & \multicolumn{6}{|c|}{ Pigments Content (mg/g. f.w.) } & \multirow{2}{*}{\multicolumn{2}{|c|}{$\begin{array}{c}\text { Total soluble } \\
\text { sugars } \\
\text { (mg/100 q. f.w.) }\end{array}$}} \\
\hline & \multicolumn{2}{|c|}{ Chlorophyll (a) } & \multicolumn{2}{|c|}{ Chlorophyll (b) } & \multicolumn{2}{|c|}{ Carotenoids } & & \\
\hline & 2014 & 2015 & 2014 & 2015 & 2014 & 2015 & 2014 & 2015 \\
\hline ontr & & 25 & 0.282 & 323 & 0.30 & & 2.223 & 2.498 \\
\hline Depu & & 1.307 & 0.436 & & & & 4.395 & 4.8 \\
\hline DS s & 1.501 & 2.088 & 0.466 & & & & & 4.989 \\
\hline & & 1.1 & & & & & & \\
\hline & 0.879 & 1.223 & 0.369 & 0.397 & 0.431 & 0.473 & 3.664 & 3.510 \\
\hline DS So & - & - & - & - & - & - & - & - \\
\hline DS Soaked in diluted $\mathrm{H}_{2} \mathrm{SO}_{4}$ for $12 \mathrm{~h}$. & - & - & - & - & - & - & - & - \\
\hline
\end{tabular}

This may be attributed to the ease permeation of water into the Pyrenes after removal the fleshy exocarp, which finally leads to increasing the amount of water by the depulped seeds and consequently increasing hydrolysis of the food reserves stored in the hard endosperm to become more available for the new formed seedlings. Similar observations were also shown by Shahin et al. (2014) on Phoenix rupicola, Junior et al. (2013) on Acrocomia aculeate and and Shahin et al. (2015) whom found that soaking the seeds of Dillenia indica in tap water for $72 \mathrm{~h}$. greatly improved chlorophyll a, b, carotenoids, total soluble sugars and total indoles in the leaves of the new formed seedlings.

According to the results mentioned above, it can be advised to soak the dopulped seeds of Phoenix roebelenii O`Brien in tap water for $24 \mathrm{~h}$. in order to get the highest and fastest germination along with the best seedling quality. 


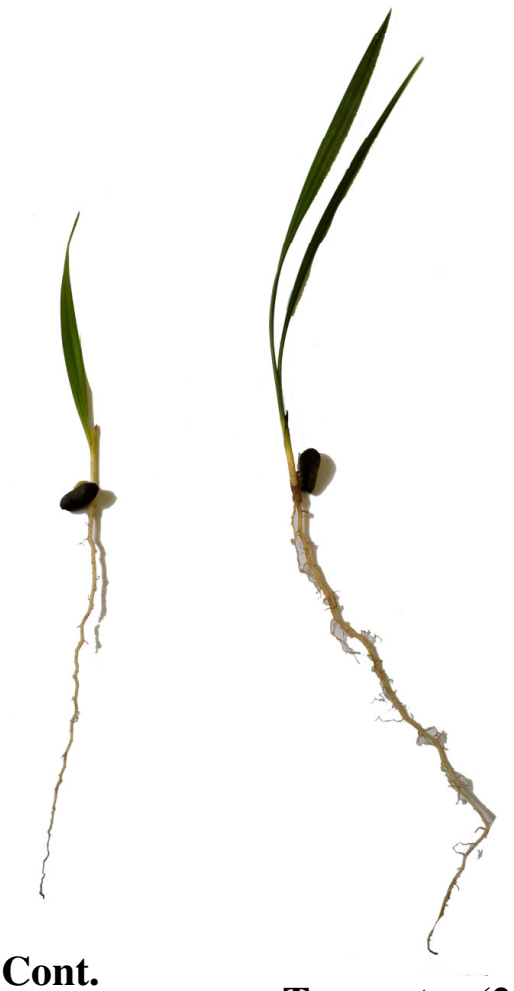

Cont.

Tap water $(24 \mathrm{~h}$.

Photo (1). A comparison between control seedling and the best treatment one (Tap water, $24 \mathrm{~h}$.).

\section{REFERENCES}

Alamgir, M. and M. K Hossain. (2005). Effect of pre-sowing treatments on germination and initial seedling development of Albizia saman in the nursery. J. Forestry Res., 16 (3): 200-204.

Al-Fredan, M. A. and Y.S.S. Ali. (2008). Seed scarification requirement in Doum (Hyphaene thebaica Mart). Scientific J. King Faisal Univ., 9 (2): 75-84.

Barrow, S. (1994). In search of Phoenix roebelenii: the Xishuangbann. Palm. Principes, 38 (4): 177-181.

Chikumba, N., C. Mapiye and X. Poshiwa. (2006). Breaking seed coat dormancy in Macrotyloma daltonii. Rangeland J., 28 (2): 179-182.

Dhanda, S. K., R. C. Verma and R. D. Panwar. (2011). Seed and seedling quality of some multipurpose tree species of arid and semi-arid regions. Environment and Ecology, 29 (1A): 442-447.

Dubois, M., F. Smith, K. A. Illes, J. K. Hamilton and P. A. Rebers. (1966). Colorimetric mehod for determination of sugars and related substances. Ann. Chem., 28 (3): 350-356.

Hartmann, H.T. and D. E. Kester. (1983). Plant Propagation: Principles and Practices. Prentice-Hall Inc., Inglewood Cliffs, N. J., 662pp.

Junior, A. G., T. G. Oliveira, P.P. de Souza, and L. M. Ribeiro. (2013). Water uptake and pregermination treatments in macaw palm (Acrocomia aculeata - Arecaceae) seeds. J. of Seed Science, 35 (1): 99-105. 
Lorenzi, H., H.M. Souza, J.T. Costa, L.S. Cerqueira, and E. Ferreira. (2004). Palmeiras brasileiras: exoticas cultivadas. Nova Odessa: Plantarum, 416 p.

Lossi, S. F. Moro, and R. Sader. (2006). Seed anatomy and germination of Phoenix roebelenii O`Brien (Arecaceae). Sements, 28 (3): 21-26.

Matthes, L. A. and C. E. Castro. (2007). Germinacao de Sementes de palmeiras. O Ageonomico, Campinas, 59 (3): 267-277.

Odetola, J. A. (1987). Studies on seed dormancy, viability and germination in ornamental palms. Principes, 31 (1): 24-30.

SAS, Institute. (2009). SAS/STAT, User`s Guides: Statistics. Vers. 9, SAS. Institute Inc. Cary, N.C., USA.

Selvaraju, P. and J. A. Selvaraj. (1994). Effect of pre-sowing treatments on germination and vigour of seed in marigold (Tagetes erecta L.). Madras Agric. J., 81 (9): 469-497.

Shahin, S.M. and Azza, M.S. Arafa. (2014) a. Germination of Butia palm seeds as affected by pregermination treatments. J. Prroduct. \& Dev., 12 (2): 401-410.

Shahin, S.M. and Azza, M.S. Arafa (2014) b. Germination of Doum palm seeds as affected by some scarification treatments. J. Prroduct. \& Dev., 12 (2): 453-462.

Shahin, S.M., Amal S. El-Fouly, and Azza M. Abdel-Moniem. (2015). Seeds of Elephant apple (Dillenia indica L.) response to some pre-germination treatments. The $1^{\text {st }}$ Conf. of SSFOP "Future of Ornam. Plants in Egypt", Feb. $22^{\text {nd }}$,Cairo, Scie. J. Flowers \& Ornam. Plants, 2 (1): 39-50.

Shahin, S.M., Amal S. El-Fouly and Magda A. Ahmed. (2014). Seeds Germination of some ornamental palms hard to germinate: 2- Seeds germination of Syagrus schizophylla (Mart) Becc. Minufiya J. Agric. Res., 39 (5): 1665-1673.

Silva, F. de A.S. and C. A. V. de Azevedo. (2009). Principal Component Analysis in the Software Assistat Statistical Attendance. In: WORLD CONGRESS ON COMPUTERS IN AGRICULTURE, 7 RenoNV-USA, Amer. Soc. of Agric. and Bio. Engineers

Steel, R. G. D. and J. H.Torrie. (1980). Principles and procedures of statistics. McGrow Hill Book Co., Inc., New York, P: 377-400.

Uhl, N.W. and J. Dransfield. (1997). Genera Palmarum: a classification of palms based on the work of Harold E.Moore Junior Lawrence: Allen Press, 610p.

Yadava, Y. L. (1986). Rapid and non-destructive methods to determine chlorophyll in intact leaves. HortScience, 21: 1449-1450. 


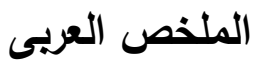

تأثير بعض معاملات ما قبل الإنبات على إنبات بذور وجودة شتلات نوعين من نخيل الزينة المتداول فى مصر

\title{
r - نخيل البلح القزمى (Phoenix roebelenii O’Brien)
}

\author{
سيا محمد شاهين وهشام فخري الطيب \\ قسم بحوث الحدائق النباتية- معهد بحوث البساتين - مركز البحوث الزراعية-الجيزة، مصر .
}

أجري هذا البحث تحت الظل بمشتل حديقة أنطونياس النبانية، معهد بحوث البسانين، الإسكندرية، مصر خلال موسمي

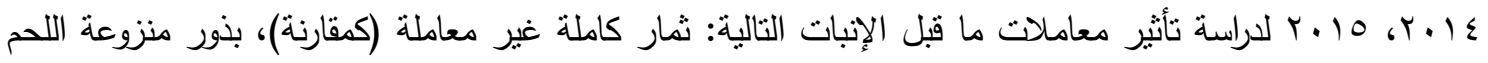

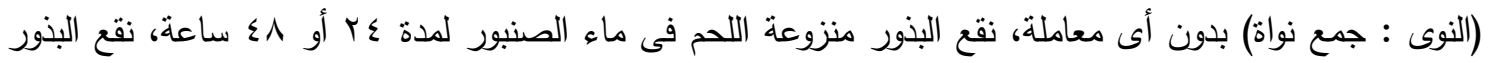

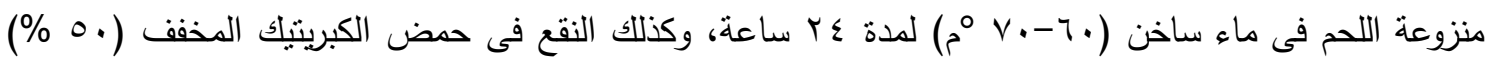

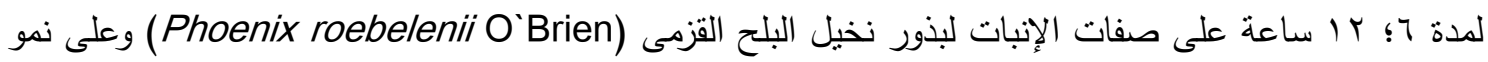
وجودة الثتلات الناتجة.

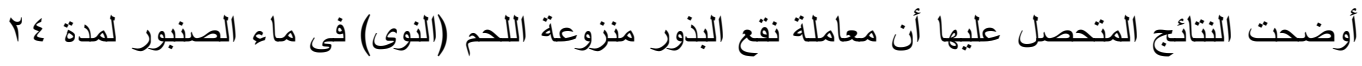
ساعة أعطت أعلى نسبة للإنبات فى كلا الموسمين، تلتها فى الموسم الأول معاملة النقع فى الماء الساخن لمدة ألماء ع r ساعة، بينما تلتها فى الموسم الثانى زراعة البذور منزوعة اللحم بدون معاملة. ولقد فثلت البذور منزوعة اللحم والمنقوعة فى حمض الكبريتيك المخفف لمدة 7 ساعات فى الإنبات، بينما أعطت تلك النى نقعت فى هذا الحمض

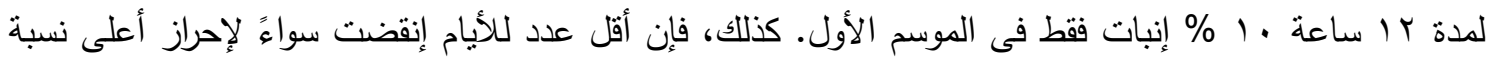
إنبات (سرعة الإنبات) أو لتحقيق •0 \% إنبات (معدل منوسط الإنبات) سجلته أيضاً معاملة النقع فى ماء

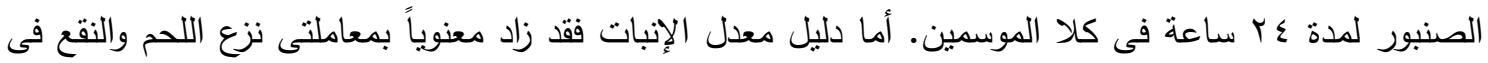

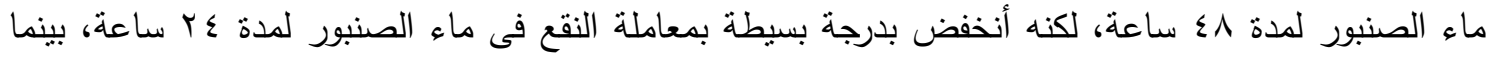

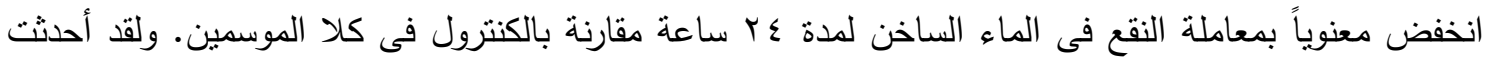

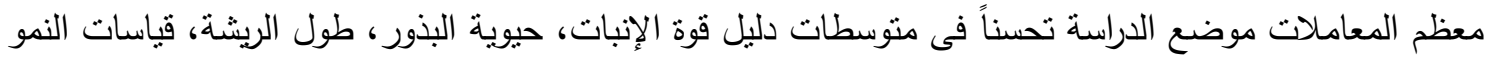
الخضرى والجذرى للشتلات الناتجة، وفى محتوى أوراقها من كلوروفيللي أ، ب، الكاروتينويدات والسكريات الكلية الذائبة وبفروق معنوية مختلفة عند مقارنتها بمتوسطات الكنترول فى معظم الحالات بكلا الموسمين. إلا أن السيادة كانت لمعاملة النقع فى ماء الصنبور لمدة \& ب ساعة والتى أعطت أعلى القيم فى معظم القياسات السابقة بكلا

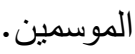

لألك، يمكن التوصية بنقع البذور منزوعة اللحم لنخيل البلح القزمى Phoenix roebelenii (O`Brien) على شتلات قوية عالية جودة. 